\title{
A Study on the Performance of Crowdsourcing Software Development
}

\author{
Tae Eun Kim ${ }^{1}$, Young Moon Lee ${ }^{2}$ and Jae Yoon Cheon ${ }^{3}$ \\ ${ }^{1,2,3}$ Department of IT Policy Management, Soongsil University, Seoul, Korea \\ ${ }^{1}$ taeeunkim@fico.com, ${ }^{2}$ kampolee1@naver.com, ${ }^{3}$ jycheon2@naver.com
}

\begin{abstract}
This research investigated a result of software development based on the crowdsourcing. An empirical study was conducted to draw the participation of software developers from requester's of crowdsourcing viewpoint and to verify the causal relationship which influences the result of software development by collaboration. The results of crowdsourcing software development could be summarized as follows. First, cooperation creation and decision making with participants who were offered monetary reward were rejected and the hypothesis which cooperation creation and decision making with participants who had favor were chosen. The hypothesis that participants and requestors made cooperation creation by honor reward was rejected but cooperation decision making was chosen. Second, every hypothesis about the effect on the result of software development by cooperation creation and decision making was chosen. Third, software characteristics, which are innovation, standardization, and flexibility, were verified on its control effect influenced software development productivity, the result showed that only flexibility had a difference in the control effect analysis.
\end{abstract}

Keywords: Crowdsourcing, Collective Intelligence Genome Framework, Open Source Software, Software Development Performance, Motivation

\section{Introduction}

The software industry is a vital component to create new value as a core industry for national economic development and its advancement as well as a necessary component for leading the Fourth Industrial Revolution. However, a competitiveness of domestic(Korea) software industry is getting left behind and there is a shortage of excellent software specialists who lead the software industry. To solve this problem, a study on software development based on the crowdsourcing by collective intelligence used in overseas might lead a development of domestic software industry and technological innovation [1].

Competitiveness in the software industry is essential to a highly qualified software professional. However, according to the report on the status of the 2016 software (information technology) industry manpower (July 8, 2016), the software industry workers in the domestic software industry was more than the average industry insufficiency rate $(2.4 \%)$ with web experts $(4.3 \%)$, software developers $(3.3 \%)$, and when looking at the status of software sector by career software engineers ' career, there are $88.4 \%$ of engineers with under 5 years of experience and $4.0 \%$ of engineers with over 9 years of experience, and excellent and experienced professional manpower is also very insufficient[2][10]. However, the software developer's treatment and working environment are becoming more difficult, and maintenance and management of competent software developers are insufficient [2].

Received (January 17, 2018), Review Result (March 5, 2018), Accepted (March 12, 2018) 
This study researches the case of software development through crowdsourcing, how to apply and utilize software development through crowdsourcing, and the effect of crowdsourcing on software development performance. To do it, various definitions of crowdsourcing are analyzed based on pieces of literature and case studies on open source software and software development by crowdsourcing are analyzed for this study. In addition, related studies were investigated by an academic definition of software engineering and the crowdsourcing that how the software development could be proceeded by crowdsourcing. The study on collective intelligence genome framework by Malone(2010) was studied as a basic model of this study and examples of collective intelligence were analyzed by genes of participation motive(Why), participation form(Who), participation purpose(What), and participation method(How)[1]. Moreover, the motivators of participants who join crowdsourcing and collective intelligence were arranged by related studies. The characteristics of software which could increase software development productivity were defined and the moderating effects on crowdsourcing software development by defined software characteristics were analyzed.

\section{Theoretical Background}

\subsection{Crowdsourcing}

Modern industrial software development projects are rarely undertaken as an individual effort. Instead, a number of people in well- defined roles work in teams to produce a set of project deliverables. Large software projects often involve several collaborating teams distributed geographically as far as on different continents [18]. The term crowdsourcing was first used by Jeff Howe in Wired Magazine in 2006 and his book defined that it is to conduct outsourcing to an unspecified number of the public through an open call of work traditionally involved in crowdsourcing. And crowdsourcing is defined as a system that connects people requiring talent and knowledge and uses a human network to find solutions if solutions are existed without making solutions to the problems [9]. Crowdsourcing is to use the collective intelligence (Open Collaboration) for the public to raise the competitiveness of the technology and organization to maximize the profit of the enterprise when technology power among companies and countries are decreasing due to the development Internet, and solve the technical and scientific problems and create a new business opportunity through innovation of technology and organization [2][17]. Crowdsourcing is a knowledge sharing framework that brings out the maximum effect with minimum cost.

\subsection{Malone's Collective Intelligence Genes}

Open Collaboration in the book of William Morton Wheeler, and American entomologist, entitled "Ant: Their Structure, Development, and Behavior", is mentioned as the concept first suggested, is talking about collective ability acquired through many objects' mutual cooperation or competition, while observing the process that termites that are very small in terms object make scientifically excellent and huge ants house through collaboration[3], and it can be defined as the assertion that the integrated intelligence of a group with diversity and independence is closer to the correct conclusion than the ability of a few excellent individuals or experts.

Malone et al., (2010) proposed a framework for analyzing collective intelligence by collecting and organizing 250 cases using collective intelligence through Internet-based services, organizing conceptual elements of collective intelligence and extracting common elements. This study analyzed the cases of each collective intelligence through two questions (1. who is performing the task? why are they doing it? 2. What is being accomplished? How is it being done?), and defined the genes in each collective intelligence. The study analyzes the cases of each collective intelligence using the 
questions and presents the framework of how the collective intelligence is performed and who participates by dividing it into four dimensions as shown in Figure 1.

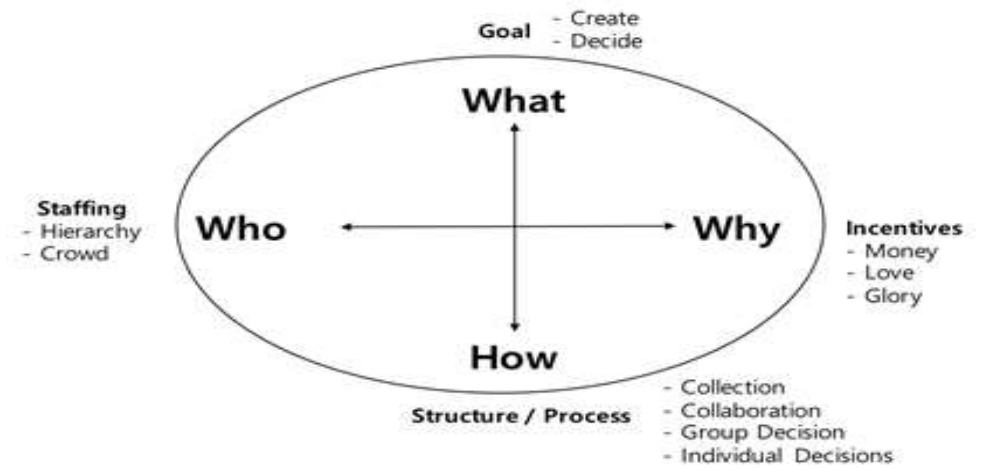

Figure 1. Elements of Collective Intelligence (Malone et al.(2010) pp.22-23 Reconstruction)

In the study, we used the questions of naming the elements of collective intelligence as genes through biological analogies and why and how they participated in collective intelligence and how and what they achieved [2].

Echebarria et al., (2011) were looking at ways to disseminate best practices among local governments through the promotion of the Local Agenda 21 (hereinafter LA21) in Basque City and conducted the research through case studies using the Policy Network for the LA21 for 8 years. The policy network is a collective intelligence system based on social networks, and the effect of collective intelligence loyalty on local municipalities is analyzed using the collective intelligence genome of Malone et al., (2010), and the cooperative decision making, cooperative creation, affection, glory, and money [12]. It suggested the result that leaders could encourage co-creation using external motivational tools through monetary and honorable rewards, and cooperative creation, cooperative decision-making, and affection had a positive impact on commitment to LA21.

\subsection{Study on Motivation Factors of Crowdsourcing Participation}

The first motivator chosen by Malone et al., (2010) is monetary compensation [11]. Money is a motivating factor when it comes to paying directly, like salary, increasing reputation, or improving your technical skills to increase your potential for future profits. The second motivator is affection [11]. Affection is described as an important motivator to engage in many situations, even if there is no financial benefit. It is defined that participants are satisfied with contributing to the intrinsic enjoyment of participation, the opportunity to make friendships with others, and something other than themselves. Thirdly, the motivating factor is Glory, which can be explained by the recognition and honor of others [11]. Glory is an example of the motivators that programmers in the open source software community have a high desire for recognition of their contributions.

Kaufmann et al., (2011) conducted a survey to investigate the motivation for participants to participate in crowdsourcing Amazon Mechanical Turk platform by paying fees [13]. This study selected pastime (killing time) to select participants as technological diversity, business sense, work autonomy, and direct feedback factors as internal motivational factors for enjoyment. Technology diversity means to participate in what they do well or like, and the sense of work unity allows them to see how the results of their work are utilized in the future, motivated by providing the visibility of work. Work autonomy refers to the autonomy of the work that is allowed to the worker during the participatory work, and direct feedback provides an opportunity to verify that the outcome of the work is correct. And because crowdsourcing utilizes the Internet-based community, 
this study selected community characteristics and relationship formation as a motivator of community-based motivation.

Immediate payment and delayed payment were used as external motivation factors. Immediate payment is a monetary reward for the completion of work and is provided for use as a primary or secondary income form of the participant. Delayed payments are a form of strategic participation for the opportunities now or in the future and are motivators for participating in presenting themselves strategically to current or future employers strengthening competence has improved its skills and abilities and used it as an incentive for current work or better jobs. Social motivation includes participation in external values, participation according to external norms or obligations, and indirect feedback. Participation in external values is, for example, the value pursued by the platform or the value pursued by the community is important and participates in order to adhere to its value, and the meaning of the external norm or obligation is to follow the obligation of the participant or the social norm that participant has.

The research showed that the amount of compensation is not so much, but immediate payment was found to be the greatest motivation for participating, and the technology diversity, job integrity, and work autonomy were found to record high scores, and it was studied to have much influence not by money, but by pleasure as for the reason participants take part in paid crowdsourcing.

\subsection{Study on Software Characteristics}

Software development is becoming more complex and the scale of development is increasing dramatically. As complexity and scale grow, the risks to cost, quality, and delivery of software development projects are more increasing. To reduce project and software development risks and increase software productivity and development performance, companies and project organizations are introducing new development tools or innovative technologies and standardizing software development processes to improve quality. Also, to increase the flexibility of the software structure and to integrate with various technologies, they emphasize the flexibility to cope with the scale of the software and the technical convergence of the industry. In the study of Choi, Moon Jong (2013) on these characteristics of software, it presented the results of the study that software innovation, standardization, and flexibility have an influence on the technical performance of the company [14]. In a case study of crowdsourcing software development, Klaas-Jan and Brian (2014) suggested that the task division, communication method, scheduling, quality control, intellectual property rights, benefits, and motivation should be considered for crowdsourcing software development [15]. Here, they explained in the study that standardization for project management is required for collaboration, and flexibility is required for integration of the outputs created through effective division of labor.

The change cycle of software development technology and the software industry have reduced dramatically, and new technology and industry trends have also shortened its life cycle. Software development must understand and apply ongoing industry trends and new technologies to improve the value of software. Innovation provides an opportunity to quickly adapt to the internal and external environment and to advance the market through technical superiority and improve the value of the enterprise. Innovation is to develop or introduce software by applying new technology concepts, delivering innovative and stateof-the-art software, effectively delivering the value of a product or software to its customers. Innovation is defined as the ability or tendency for an organization to innovate or create new products, services, and values [8]. In addition, innovation is a behavioral variable that can be categorized into two kinds that quantitative measurement of organization who introduce innovation and intention for change and innovation of the organization [5]. De Leeuw and Volberda (1996) define flexibility as an agility in the organizational environment that implements procedures through the potential and actual procedural degrees that organizations have to improve their control capabilities and 
competencies [6][7]. Byrd \& Turner (2000) define flexibility as an ability to modify and extend the hardware and software-related technologies within the technical platform, and as the capability to divide various information in and out of an organization [16]. Generalizing the studies of software flexibility, it shows that flexibility increases the adaptability of the environment to software development, which significantly affects on project performance and firm performance. Previous studies have shown that the research related to flexibility depends on the software perspective, the project perspective, the software development team perspective, and the enterprise perspective. A standard is a unified/simplified regulation of things, concepts, methods, procedures, etc. and has a nature like a certain promise. Software development has various tools and procedures related to the development and the output of each project varies according to the nature of the project, and in order to develop software effectively, the project manager applies software contract standard document, requirement analysis standard, design standard, coding standard, test standard. Standards related to software development have the effect of supporting reasonable communication of various stakeholders involved in software development and reducing project risk.

\section{Research Design}

\subsection{Research Model}

As shown in Figure 2, the research model was suggested based on Malone et al., (2010) theory of collective intelligence genes. As independent variables, Money Rewards, Glorious Rewards, and Love were selected. Collaborative Creation and Decision making were selected as mediating variables and software characteristics such as Innovation, Standardization, and Flexibility were selected as control variables. The dependent variable is Software Development Performance. SPSS version 18 statistics software and AMOS version 18 software were used for verification of the study hypothesis. To verify its hypothesis, general people who work for software industry were targeted and 88 out of 200 questionnaires were collected from offline and 151 out of 239 questionnaires were collected from online. The answers which had missing data or were impertinent were ruled out from the collected answers and 221 answers were used for final analysis.

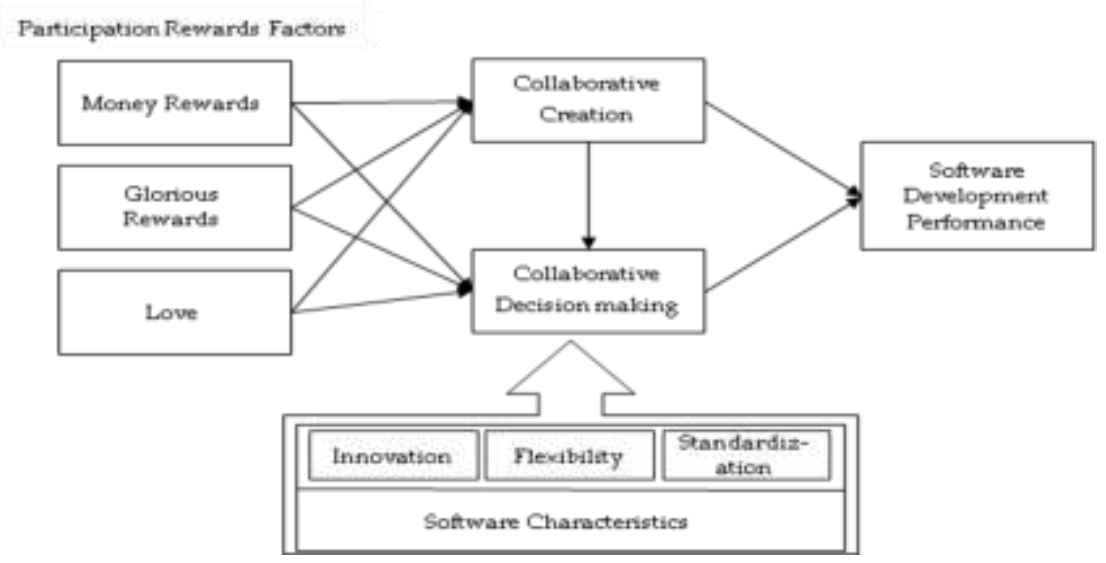

Figure 2. Research Model

\subsection{Hypothesis Setting}

Hypothesis 1: Monetary compensation will have a positive (+) impact on cooperative creation. 
Hypothesis 2: Monetary compensation will have a positive (+) impact on cooperative creation.

Hypothesis 3: Favorability for participation will have a positive impact (+) on cooperative creation

Hypothesis 4: Monetary compensation will have a positive (+) impact on cooperative decision making.

Hypothesis 5: Honorary compensation will have a positive (+) impact on cooperative decision making.

Hypothesis 6: Favorability for participation will have a positive impact (+) on cooperative decision making.

Hypothesis 7: Cooperation creation will have a positive (+) impact on cooperative decision making.

Hypothesis 8: Cooperative creation will have a positive impact $(+)$ on software development performance.

Hypothesis 9: Cooperative decision making will have a positive impact (+) on software development performance.

Hypothesis 10: Software innovation will have a controlling effect.

Hypothesis 11: Software standardization will have a controlling effect.

Hypothesis 12: Software flexibility will have a controlling effect.

\section{Empirical Analysis}

\subsection{Characteristics of Samples}

To conduct research on the software development performance of the crowdsourcingbased software development of this study, the questionnaire was conducted online and offline by selecting the persons who are working in the IT industry related to software development, the project team leader, and the software developers.

The age of 40 s accounted for $61.5 \%$ of all surveys and $67.4 \%$ of all project managers or mid-managers who participated in decision making in the software project were judged to be suitable for the questionnaire. $78 \%$ of the respondents in the survey had over 10 years of experience, and over $30 \%$ of the professionals in the software industry, $16 \%$ in the management and management organization, and $41 \%$ in the technical staff. The profession is identified as persons qualified as technicians related to information and communication in case of having a professional qualification related to software, and the office technician is identified as persons participating in software development and operation. When analyzing the current job duties of participants, $82 \%$ of all participants are currently working on software development or development-related work, and $45 \%$ of participants are in application software development. Most of the entire respondents are involved in software development work, so they can be judged to be suitable for the questionnaire for research.

\subsection{Exploratory Factor Analysis}

In order to verify the research model, exploratory factor analysis was conducted using SPSS version 18, a statistical analysis software for validity and reliability analysis. The exploratory factor analysis conducted to verify the validity was conducted by exploring the linkage of the inherent factors of the observed variables and determining the structure between the factors and the factors, and the principal component analysis was carried out 
and the Varimax was used for rotation method of factors. In factor analysis, it is used as a significant variable when the factor load of 0.4 or more and an important variable if the factor load is 0.5 more, so 0.5 was used as the threshold value. To measure the reliability of the study, the Cronbach alpha coefficient was used and the measurement coefficient was set to a threshold of 0.7 . The Cronbach alpha coefficient is evaluated as an acceptable reliability for 0.6 or better, a good reliability of 0.7 or better, and a very high reliability of 0.8 or better [4]. As seen in Table 1, this study has a very high reliability because Cronbach's alpha coefficients are all above 0.8 .

\section{Table 1. Results of Reliability Testing}

\begin{tabular}{|c|c|c|c|c|c|c|c|c|}
\hline Innovation & $\begin{array}{c}\text { Cooperative } \\
\text { will }\end{array}$ & $\begin{array}{c}\text { Cooperative } \\
\text { creation }\end{array}$ & $\begin{array}{c}\text { Development } \\
\text { performance }\end{array}$ & $\begin{array}{c}\text { Honorary } \\
\text { reward }\end{array}$ & $\begin{array}{c}\text { Monetary } \\
\text { compensation }\end{array}$ & Flexibility & $\begin{array}{c}\text { Standardization } \\
\text { Participation } \\
\text { favors }\end{array}$ \\
\hline 0.928 & 0.903 & 0.885 & 0.872 & 0.909 & 0.872 & 0.880 & 0.930 & 0.850 \\
\hline
\end{tabular}

\subsection{Confirmatory Factor Analysis}

The fit index of the study model was $x^{2}=565.501(\mathrm{p}=0.0000), \mathrm{x}^{2} / \mathrm{df}=1.991, \mathrm{RMSEA}$ $=0.067, \mathrm{RMR}=0.089, \mathrm{GFI}=0.837, \mathrm{AGFI}=0.799, \mathrm{PGFI}=0.677, \mathrm{NFI}=0.863, \mathrm{CFI}=$ 0.926. As shown in Table 2, all measurements were included in the threshold range and indices showed a good level, so the overall fit of the study model was judged to be appropriate.

Table 2. Model Fit

\begin{tabular}{|c|c|c|c|c|c|c|}
\hline $\mathbf{x}^{2}(\mathbf{p})$ & $\mathbf{x}^{2} / \mathbf{d f}$ & RMSEA & GFI & AGFI & NFI & CFI \\
\hline $\mathrm{p} \leqq 0.05 \sim 0.1$ & $1.0 \leqq \mathrm{x}^{2} / \mathrm{df} \leqq 3.0$ & $\leqq 0.05 \sim 0.08$ & $\geqq 0.8 \sim 0.9$ & $\geqq 0.8 \sim 0.9$ & $\geqq 0.8 \sim 0.9$ & $\geqq 0.8 \sim 0.9$ \\
\hline $565.501(\mathrm{p}=0.000)$ & 1.991 & 0.067 & 0.837 & 0.799 & 0.863 & 0.926 \\
\hline
\end{tabular}

The Contsruct Validity is evaluated by CR(Composite Reliability) and AVE(Average Cariance Extracted). CR are AVE are acceptable for 0.7 or better and 0.5 or better, respectively[4]. As presented in Table 3, this study has good results because CR values are over 0.7 and AVE values are over 0.5 .

Table 3. Results of Confirmatory Factor Analysis

\begin{tabular}{|c|c|c|c|c|c|c|}
\hline & $\begin{array}{c}\text { Monetary } \\
\text { compensation }\end{array}$ & Honorary reward & $\begin{array}{c}\text { Participation } \\
\text { favors }\end{array}$ & $\begin{array}{c}\text { Cooperative } \\
\text { creation }\end{array}$ & Cooperative will & $\begin{array}{c}\text { Development } \\
\text { performance }\end{array}$ \\
\hline CR & 0.926 & 0.896 & 0.804 & 0.842 & 0.858 & 0.938 \\
\hline AVE & 0.757 & 0.636 & 0.577 & 0.640 & 0.672 & 0.790 \\
\hline
\end{tabular}

The discriminant validity is the degree of difference between the different potential variables, and it is judged that there is a validity of discrimination when there is a low correlation, and the discriminant validity is secured between the two potential variables when the correlation coefficient of latent variable is bigger than the square of the correlation coefficient[4]. As shown in Table 4, Discrimination Feasibility is secured because the square of the correlation coefficient $(0.561=0.749 \times 0.749)$ is smaller than AVE.

Table 4. Discrimination Feasibility of Confirmatory Factor Analysis

\begin{tabular}{|c|c|c|c|c|c|c|}
\hline & MON & REP & LOV & COC & COD & RES \\
\hline MON & $\mathbf{0 . 6 6 1}$ & & & & & \\
\hline REP & 0.642 & $\mathbf{0 . 7 1 8}$ & & & & \\
\hline LOV & 0.630 & 0.744 & $\mathbf{0 . 6 5 8}$ & & & \\
\hline COC & 0.396 & 0.588 & 0.527 & $\mathbf{0 . 5 6 9}$ & & \\
\hline COD & 0.396 & 0.558 & 0.567 & $\underline{0.749}$ & $\mathbf{0 . 6 4 5}$ & \\
\hline RES & 0.308 & 0.417 & 0.432 & 0.611 & 0.658 & $\mathbf{0 . 5 9 7}$ \\
\hline
\end{tabular}




\subsection{Hypothesis Verification}

As seen in Table 5, 3 hypotheses, which monetary reward $\rightarrow$ cooperation creation, monetary reward $\rightarrow$ cooperation decision making and honorary reward $\rightarrow$ cooperation decision making, were rejected but all other hypotheses were adopted.

Table 5. Measuring Causal Relation through Path Analysis

\begin{tabular}{|c|c|c|c|c|c|c|c|}
\hline \multicolumn{3}{|c|}{ Path } & Path coefficient & Standard error & CR & $\mathbf{P}$ & \begin{tabular}{|l} 
Judgment \\
\end{tabular} \\
\hline \multirow{3}{*}{$\begin{array}{l}\text { Cooperation } \\
\text { creation }\end{array}$} & $\leftarrow$ & $\begin{array}{c}\text { Monetary } \\
\text { compensation }\end{array}$ & -0.015 & 0.065 & -0.242 & 0.813 & Rejected \\
\hline & $\leftarrow$ & Honorary reward & 0.345 & 0.089 & 3.883 & $* * *$ & Adopted \\
\hline & $\leftarrow$ & Participation favors & 0.192 & 0.106 & 1.817 & 0.069 & Adopted \\
\hline \multirow{4}{*}{$\begin{array}{l}\text { Cooperation } \\
\text { will }\end{array}$} & $\leftarrow$ & $\begin{array}{c}\text { Monetary } \\
\text { compensation }\end{array}$ & -0.007 & 0.052 & -0.144 & 0.886 & Rejected \\
\hline & $\leftarrow$ & Honorary reward & 0.029 & 0.073 & 0.397 & 0.691 & Rejected \\
\hline & $\leftarrow$ & Participation favors & 0.192 & 0.085 & 2.141 & $0.025^{*}$ & Adopted \\
\hline & $\leftarrow$ & $\begin{array}{l}\text { Cooperative } \\
\text { creation }\end{array}$ & 0.578 & 0.078 & 7.430 & $* * *$ & Adopted \\
\hline \multirow{2}{*}{$\begin{array}{l}\text { Development } \\
\text { result }\end{array}$} & $\leftarrow$ & $\begin{array}{l}\text { Cooperative } \\
\text { creation }\end{array}$ & 0.265 & 0.103 & 2.571 & $0.01^{* *}$ & Adopted \\
\hline & $\leftarrow$ & Cooperative will & 0.483 & 0.113 & 4.279 & $* * *$ & Adopted \\
\hline
\end{tabular}

\subsection{Control Effect Analysis}

As shown in Table 6 and Table 7, the significance level of the non-constraint and constraint models between the two groups is greater than 0.05 , so there is no difference between the two groups. This explains that there is no impact on the software development performance due to innovation-comparative inter-group participation compensation factors.

Table 6. Cross-Feasibility between Innovation Difference Groups

\begin{tabular}{|c|c|c|}
\hline Division & Non-constrained model & Constrained model \\
\hline $\mathrm{X}^{2}$ & 1055.614 & 1079.875 \\
\hline $\mathrm{x}^{2}$ difference & \multicolumn{3}{|c|}{24.261} \\
\hline P-value of $\mathrm{x}^{2}$ difference & \multicolumn{2}{|c|}{0.231} \\
\hline
\end{tabular}

Table 7. Controlling Variable Effect by Innovation

\begin{tabular}{|c|c|c|}
\hline Division & Non-constrained model & Constrained model \\
\hline $\mathrm{x}^{2}$ & 1059.983 & 1096.173 \\
\hline $\mathrm{x}^{2}$ difference & \multicolumn{3}{|c|}{36.190} \\
\hline P-value of $\mathrm{x}^{2}$ difference & \multicolumn{3}{|c|}{0.168} \\
\hline
\end{tabular}

As shown in Table 8 and Table 9, the significance level p- value of 0.105 , which is greater than 0.05 , can be interpreted as having no difference according to the standardization between comparisons and can be interpreted as having no controlling effect. The controlling effect analysis on the standardization can be interpreted that the cross-validity is secured between the two divided groups and they have the same measurement identity, but the control effect is not shown between the two groups.

Table 8. Cross-Feasibility between Standardization Difference Groups

\begin{tabular}{|c|c|c|}
\hline Division & Non-constrained model & Constrained model \\
\hline $\mathrm{x}^{2}$ & 973.504 & 1004.81 \\
\hline $\mathrm{x}^{2}$ difference & \multicolumn{3}{|c|}{} \\
\hline P-value of $\mathrm{x}^{2}$ difference & \multicolumn{2}{|c|}{0.051 .306} \\
\hline
\end{tabular}


Table 9. Controlling Variable Effect by Standardization

\begin{tabular}{|c|c|c|}
\hline Division & Non-constrained model & Constrained model \\
\hline $\mathrm{x}^{2}$ & 984.678 & 1023.516 \\
\hline $\mathrm{x}^{2}$ difference & \multicolumn{2}{|c|}{38.838} \\
\hline $\mathrm{P}$-value of $\mathrm{x}^{2}$ difference & \multicolumn{2}{|c|}{0.105} \\
\hline
\end{tabular}

As shown in Table 10 and Table 11, as a result of comparing the flexibility group and the non-flexibility group, it can be judged that there is a difference between the two groups because the significance level is less than 0.05 .

Table 10. Cross-Feasibility between Flexibility Difference Groups

\begin{tabular}{|c|c|c|}
\hline Division & Non-constrained model & Constrained model \\
\hline $\mathrm{X}^{2}$ & 1008.263 & 1025.383 \\
\hline $\mathrm{x}^{2}$ difference & & 17.12 \\
\hline P-value of $\mathrm{x}^{2}$ difference & \multicolumn{2}{|c|}{0.645} \\
\hline
\end{tabular}

Table 11. Controlling Variable Effect by Flexibility

\begin{tabular}{|c|c|c|}
\hline Division & Non-constrained model & Constrained model \\
\hline $\mathrm{x}^{2}$ & 1024.177 & 1053.412 \\
\hline $\mathrm{x}^{2}$ difference & \multicolumn{2}{|c|}{29.235} \\
\hline P-value of $\mathrm{x}^{2}$ difference & \multicolumn{2}{|c|}{0.007} \\
\hline
\end{tabular}

As seen in Table 12, analysis of the differences between the two groups showed that cooperative decision-making was rejected in Participation favors $\rightarrow$ cooperative decisionmaking in low flexibility group and cooperative decision- making was adopted in the flexible group. This can be interpreted as the ability of the flexible group to make and use decision-making by negotiating with the participants through various methods.

Table 12. Controlling Effect Analysis Result upon Flexibility

\begin{tabular}{|c|c|c|c|c|c|c|c|c|}
\hline \multirow{2}{*}{\multicolumn{3}{|c|}{ Path }} & \multicolumn{3}{|c|}{ Low Flexibility (117) } & \multicolumn{3}{|c|}{ Has Flexibility (104) } \\
\hline & & & \multirow{2}{*}{$\begin{array}{c}\text { Path coefficient } \\
0.066 \\
\end{array}$} & \multirow{2}{*}{$\frac{\mathbf{P}}{0.450}$} & \multirow{2}{*}{$\begin{array}{l}\text { Results } \\
\text { Rejected }\end{array}$} & \multirow{2}{*}{\begin{tabular}{|c|} 
Path coefficient \\
-0.113 \\
\end{tabular}} & \multirow{2}{*}{\begin{tabular}{|c|}
$\mathbf{P}$ \\
0.271 \\
\end{tabular}} & \multirow{2}{*}{$\begin{array}{l}\text { Results } \\
\text { Rejected }\end{array}$} \\
\hline \multirow{3}{*}{$\begin{array}{l}\text { Cooperation } \\
\text { Creation }\end{array}$} & $\leftarrow$ & $\begin{array}{c}\text { Monetary } \\
\text { reward }\end{array}$ & & & & & & \\
\hline & $\leftarrow$ & $\begin{array}{c}\text { Honorary } \\
\text { reward }\end{array}$ & 0.349 & $0.005 * *$ & Adopted & 0.366 & $0.009 * *$ & Adopted \\
\hline & $\leftarrow$ & $\begin{array}{c}\text { Participation } \\
\text { favors }\end{array}$ & 0.120 & 0.520 & Rejected & 0.200 & 0.104 & Rejected \\
\hline \multirow{4}{*}{$\begin{array}{l}\text { Cooperation } \\
\text { Decision-making }\end{array}$} & $\leftarrow$ & Monetary & -0.029 & 0.620 & Rejected & 0.034 & 0.707 & Rejected \\
\hline & $\leftarrow$ & Honorable & 0.140 & 0.113 & Rejected & -0.068 & 0.590 & Rejected \\
\hline & $\leftarrow$ & $\begin{array}{c}\text { Participation } \\
\text { favors }\end{array}$ & 0.097 & 0.447 & Rejected & 0.246 & $0.025 *$ & Adopted \\
\hline & $\leftarrow$ & $\begin{array}{c}\text { Cooperative } \\
\text { creation }\end{array}$ & 0.454 & $* * *$ & Adopted & 0.654 & $* * *$ & Adopted \\
\hline \multirow{2}{*}{$\begin{array}{l}\text { Development } \\
\text { Performance }\end{array}$} & $\leftarrow$ & $\begin{array}{c}\text { Cooperative } \\
\text { creation }\end{array}$ & 0.411 & $0.008 * *$ & Adopted & 0.506 & $* * *$ & Adopted \\
\hline & & $\begin{array}{c}\text { Cooperation } \\
\text { decision making }\end{array}$ & 0.441 & $* * *$ & Adopted & 0.052 & 0.733 & Rejected \\
\hline
\end{tabular}

\section{Conclusion}

This study investigated the performance of software development based on the crowdsourcing. An empirical study was conducted to draw the participation of software developers who are specialists from requester's of crowdsourcing viewpoint and to verify the causal relationship which influences the result of software development by collaboration. The results of the study are summarized as follows.

First, the hypothesis that monetary compensation, in ordering party's viewpoint, would effect on the cooperative creation and cooperative decision-making was rejected. From 
the perspective of participants, monetary rewards are the most important factor in promoting participation in various studies. However, in this study, the participants showed that the monetary reward did not affect the cooperation creation and cooperative decision making. This is because the domestic buyers have a negative perception on the performance of crowdsourcing due to lack of cases, and there is no process to utilize crowdsourcing, and judging that the risk against crowdsourcing operation is high. Second, the hypothesis that honorary compensation would have a significant effect on cooperative creation but, not on cooperative decision-making was rejected. From the ordering party's point of view, it can be explained that it is desirable to recognize the reputation of the participants, to recognize them as participation in community service, and to provide opportunities to participate in organizations or companies they prefer to gain recognition. However, in the case of cooperative decision making, the participant may have unconditional support for the opinion of the ordering party or the decision to receive the approval of the ordering party or a problem of collective thinking about not having criticism in agreement with the judgment that ordering party is more professional. For this reason, it can be interpreted that it is dismissed due to the reason that the ordering party judges there is a problem in the decision of cooperation with the participant through honorary compensation plan. Third, the hypothesis that cooperative creation and cooperative decision making would have a significant effect was adopted by the favor of participant. It can be explained that the outputs of cooperation creation made through their passion and enjoyment with their favor would bring good results, and the results of the study show that they can make good decision-making by raising and discussing various opinions so that the participant can comfortably take part in the decision-making process based on the favor of the participant. Fourth, collaborative creation and cooperative decision making through collective intelligence had positive effects on software development performance. Software development has complex processes that meet the needs of various stakeholders and apply new technologies. The reason for utilizing crowdsourcing for software development is that it can deduct planning, production, and consumption of products through problems in current software development, technical difficulties, innovation in software products and Omni-sumer role of participants. Fifth, the hypothesis that collaborative decision making would affect software development performance for groups with high flexibility was rejected. It can be interpreted that the decisions of collaborative decision making do not affect on the performance of software development because it is possible to decide various decision tasks in a highly flexible group through consultation and to easily change the decisions. In order to maximize the performance of software development through crowdsourcing, it is necessary to involve professional and competent software experts. The study so far was conducted to investigate the intrinsic and extrinsic motivation factors of participants in order to study participants' intention to participate. However, even though many participants participate, motivation factors of participants can be changed according to external and internal environmental factor from the perspective of the ordering party who wants to develop software through crowdsourcing. As a result of the study, the results of providing only non-monetary reward factors as compensation factors from the ordering party 's point of view can be interpreted in the same context as other study cases that lack recognition of crowdsourcing in domestic. In order to utilize the collective intelligence through crowdsourcing in Korea, it is necessary to further discuss the spread of awareness about crowdsourcing and various successful cases.

This study only used the participation motivation to verify software development performance. This might be the limitation of this study. The strategy of application and management plan for crowdsourcing might be different in accordance with characteristics by lifestyles of software. Studies for the strategy of application and management plan for crowdsourcing by lifestyles of software might be needed for the crowdsourcing based software researches in the future. 


\section{Acknowledgments}

This paper is a revised and expanded version of a paper entitled "A Study on the Performance of Crowdsourcing Software Development Applying Collective Intelligence Genome Framework" presented at 14th 2017 International Interdisciplinary Workshop (Daejeon, Korea) in December 21-23 2017.

\section{References}

[1] T. Eun Kim, "A Study on the Performance of Software Development based on Crowdsourcing", PhD Thesis, Soonsil University, (2017).

[2] T. Eun Kim, Y. Moon Lee, J. Yoon Cheon, J. Bae Kim and G. Yong Gim, “A Study on the Performance of Crowdsourcing Software Development Applying Collective Intelligence Genome Framework", Proceedings of the 14th 2017 International Interdisciplinary Workshop, Daejeon, Korea, (2017) December 21-23.

[3] D. Kim, "Seeking to utilize 'collective intelligence' for the future vision", R\&D Promotion Division of Korea Health Industry Development Institute, (2013).

[4] G. Shin, "Following Amos 20 Statistical Analysis", Cheongram Books, Seoul, Korea (2013).

[5] J. Lee, "The Analysis of the Impact of Financial Innovation on Service Innovation Performance", $\mathrm{PhD}$ Thesis, Konkuk University Graduate School, (2015).

[6] S. Jeong, "Influence of Information Technology Infrastructure Flexibility on New Product Competitive Advantage", PhD Thesis, Yonsei University Graduate School, (2005).

[7] A. CJ De Leeuw and H. W. Volberda, "On the concept of flexibility: a dual control perspective", Omega, vol. 24, no. 2, (1996), pp. 121-139.

[8] R. Garcia and R. Calantone, "A Critical Look at Technological Innovation Typology and Innovativeness Terminology: A Literature Review", The Journal of Product Innovation Management, vol. 19, no. 2, (2002), pp. 110-132.

[9] J. Howe, "Crowdsourcing: Why the Power of the Crowd Is Driving the Future of Business", Crown Business, (2008).

[10] Industry Skills Council, “2016 SW(IT) Industry Manpower Status Report”, KOSA, (2016).

[11] T. W. Malone, R. Laubacher and C. Dellarocas, "The Collective Intelligence Genome: Sloan Management Review", (Reprint No. 51303), vol. 51, no. 3, (2010), pp. 21-31.

[12] C. Echebarria and J. M. Barrutia, "Managing Policy Networks: A Social Marketing-And Collective Intelligence Systems-Driven View", Conference paper of 51st Congress of the European Regional Science Association: "New Challenges for European Regions and Urban Areas in a Globalised World", Barcelona, Spain, (2011) August 30-September 3.

[13] N. Kaufmann, T. Schulze and D. Veit, "More than fun and money. Worker Motivation in Crowdsourcing-A Study on Mechanical Turk", AMCIS, vol. 11, no. 2011, (2011), pp. 1-11.

[14] M. Jong Choi, "Effects of Entrepreneur Characteristics and Software Innovativeness on Performance of Software Company: The Moderating Effects of Institutional Pressure", PhD Thesis, Kyungpook National University Graduate School, (2013).

[15] K.-J. Stol and B. Fitzgerald, "Two's company, three's a crowd: a case study of crowdsourcing software development", Proceedings of the 36th International Conference on Software Engineering, Hyderabad, India, (2014) May 31-June 07.

[16] T. Anthony Byrd and D. E. Turner, "Measuring the flexibility of information technology infrastructure: Exploratory analysis of a construct", Journal of Management Information Systems, vol. 17, no. 1, (2000), pp. 167-208.

[17] J. Choi and H. Lee, "Technology valuation utilizing crowd sourcing approach", Asia-pacific Journal of Multimedia Services Convergent with Art, Humanities, and Sociology, ISSN:2383-5281, vol. 6, no. 6, (2016), pp. 403-412.

[18] S. Kurkovsky, "Instructor's Roles in Software Engineering Course Projects”, International Journal of Advanced Science and Technology, SERSC Australia, ISSN: 2005-4238 (Print); 2207-6360 (Online), vol. 1, (2008), pp. 75-84. 
International Journal of Advanced Science and Technology

Vol.118 (2018) 